NBER WORKING PAPER SERIES

\title{
EFFECTS OF STATE-LEVEL EARNED INCOME TAX CREDIT LAWS IN THE U.S. ON MATERNAL HEALTH BEHAVIORS AND INFANT HEALTH OUTCOMES
}

\author{
Sara Markowitz \\ Kelli A. Komro \\ Melvin D. Livingston \\ Otto Lenhart \\ Alexander C. Wagenaar \\ Working Paper 23714 \\ http://www.nber.org/papers/w23714
}

\author{
NATIONAL BUREAU OF ECONOMIC RESEARCH \\ 1050 Massachusetts Avenue \\ Cambridge, MA 02138 \\ August 2017
}

The National Institute on Minority Health and Health Disparities, National Institutes of Health supported this work (award R01MD010241). We thank Scott Burris, JD and Lindsay K. Cloud, JD with Temple University Beasley School of Law and the LawAtlas team for legal scholarship and coding. The views expressed herein are those of the authors and do not necessarily reflect the views of the National Bureau of Economic Research.

NBER working papers are circulated for discussion and comment purposes. They have not been peer-reviewed or been subject to the review by the NBER Board of Directors that accompanies official NBER publications.

(C) 2017 by Sara Markowitz, Kelli A. Komro, Melvin D. Livingston, Otto Lenhart, and Alexander C. Wagenaar. All rights reserved. Short sections of text, not to exceed two paragraphs, may be quoted without explicit permission provided that full credit, including $(\subset$ notice, is given to the source. 
Effects of State-Level Earned Income Tax Credit Laws in the U.S. on Maternal Health Behaviors and Infant Health Outcomes

Sara Markowitz, Kelli A. Komro, Melvin D. Livingston, Otto Lenhart, and Alexander C. Wagenaar NBER Working Paper No. 23714

August 2017

JEL No. H0,I0

\section{ABSTRACT}

The purpose of this paper is to investigate the effects of state-level Earned Income Tax Credit (EITC) laws in the U.S. on maternal health behaviors and infant health outcomes. Using multistate, multi-year difference-in-differences analyses, we estimated effects of state EITC generosity on maternal health behaviors, birth weight and gestation weeks. We find little difference in maternal health behaviors associated with state-level EITC. In contrast, results for key infant health outcomes of birth weight and gestation weeks show small improvements in states with EITCs, with larger effects seen among states with more generous EITCs. Our results provide evidence for important health benefits of state-level EITC policies.

Sara Markowitz

Department of Economics

Emory University

Rich Memorial Building

1602 Fishburne Dr.

Atlanta, GA 30322

and NBER

sara.markowitz@emory.edu

Kelli A. Komro

Emory University

Rollins School of Public Health

Grace Crum Rollins Building

1518 Clifton Rd NE

Atlanta, GA 30322

kkomro@emory.edu

Melvin D. Livingston

University of North Texas Health Science Center

Department of Biostatistics and Epidemiology

3500 Camp Bowie Blvd

Fort Worth, TX 76107

Melvin.livingston@unthsc.edu
Otto Lenhart

University of West Florida

Department of Marketing and Economics 11000 University Pkwy

Pensacola, FL 32514

olenhart@uwf.edu

Alexander C. Wagenaar

Emory University

Rollins School of Public Health

Behavioral Sciences \& Health Education

Grace Crum Rollins Building

1518 Clifton Rd NE

Atlanta, GA 30322

alex.wagenaar@emory.edu 


\section{INTRODUCTION}

The U.S. Federal Earned Income Tax Credit (EITC) has been praised as the largest and most effective anti-poverty program for families in the United States (Hoynes, 2016; Marr et al., 2015). The U.S. EITC is an example of in-work family tax credits (IWTC) used in many countries around the world. The U.S. EITC is designed to supplement incomes of low-wage workers and to reduce their tax burden, while encouraging recipients to work. Administered through the income tax filing process, recipients earn a tax credit that varies with the level of earned income and with family structure. Research shows the federal program has been successful in reducing poverty and increasing labor force participation (Eissa \& Hoynes, 2006; Neumark \& Wascher, 2000; Nichols \& Rothstein, 2016), especially among single mothers. Comprehensive reviews of the federal EITC program and IWTC programs in other countries have been previously published (Hotz, 2003; Nichols \& Rothstein, 2016; Pega et al., 2013).

Beginning in 1988, U.S. states began introducing their own EITCs; just a few states at first, growing to 26 states plus Washington DC by 2016. Eleven of these established the program within the last ten years. State EITCs vary tremendously in terms of generosity, ranging from dollar values representing a mere $3.5 \%$ of the federal benefit to a high of $75 \%$ of the federal benefit. As with the federal EITC, research on state EITCs shows these state programs encourage employment among women (Strully et al., 2010).

A less studied, but perhaps equally beneficial aspect of the EITC is the program's propensity to improve recipients' health. Researchers have long recognized that income and health outcomes are closely linked (Grossman, 1972; Sorlie et al. 1995; Backlund et al. 1996); and recent studies demonstrate that individuals of low socioeconomic status suffer from worse health outcomes than wealthier ones (Case et al., 2002; Chetty et al., 2016). As discussed below, 
there are a variety of pathways through which the EITC could affect a recipient's health status, including, but not limited to, increased income allowing for the purchase of improved food, housing, medical care and other inputs into the health production function, and the reduction of financial stress. Given the known importance of income to health, policy makers should not only assess the poverty mitigation results of EITC programs, but they should also consider health effects. Improved health outcomes have far reaching long-term beneficial effects such as reduced medical care costs, improved educational outcomes for children, and increased adult labor market productivity.

In a 2013 Cochrane systematic review examining the international literature on the effects of IWTC on working age adult health status, only U.S. studies of large changes to the federal EITC met the inclusion criteria (Pega et al., 2013). The authors concluded that there was insufficient evidence due to poor study design and inconsistent findings to determine an effect of IWTC on adult health status, including health behaviors. In this paper, we contribute to the knowledge base about the effects of U.S. based EITC programs by focusing on the effects of states' EITC on infant health outcomes and maternal health behaviors. A number of studies have examined the health effects of the federal EITC while ignoring state EITCs (Averett \& Wang, 2013; Baker, 2008; Boyd-Swan et al., 2016; Evans \& Garthwaite, 2014; Hamad \& Rehkopf, 2015; Hoynes et al., 2015). These studies consistently find improvements in various measures of maternal and child health associated with the federal EITC.

The EITC can affect infant health through several channels. First, the tax credit can affect infant health by providing increases in income for individuals from low socioeconomic backgrounds. The average amount of the 2016 Federal EITC benefit was $\$ 2,455$, with a range from a low of $\$ 2$ for people with no children to a high of $\$ 6,269$ for families with three or more 
children (Internal Revenue Service, 2017). State EITCs would add to the federal dollars, with amounts varying based on state and family size. Meyer (2010) estimated the 2007 federal EITC benefits reduced the poverty rate by 10 percent and lifted over 1.1 million families above the poverty line. Literature on the EITC has established that the program successfully increases earnings and lifts individuals above the poverty threshold by encouraging work, especially among single mothers (Eissa \& Liebman, 1996; Meyer \& Rosenbaum, 2001; Hoynes \& Patel, forthcoming). The increased income resulting from either the work incentives or the cash benefits may be used by mothers to buy more health inputs (housing, medical care, nutrition, etc.), which can lead to better infant health outcomes. Previous work on the federal EITC has shown that the program increases food expenditures, specifically increasing spending on healthy groceries such as fresh fruit and vegetables (Lenhart, 2016; McGranahan \& Schanzenbach, 2013).

Second, increases in income as well as income security might lead to changes in healthrelated behaviors, such as timely receipt of prenatal care, and changes in smoking and drinking, which in turn influence birth outcomes and later childhood outcomes (Almond \& Currie, 2011). Averett and Wang (2013) and Hoynes et al. (2015) show that the federal expansion in the EITC reduced smoking among mothers. However, in a longitudinal study of New Zealand's Family Tax Credit, Pega et al. (2017) find no relationship between the cumulative receipt of the credit and tobacco smoking. Cigarettes and alcohol are typically found to be normal goods (i.e., amount purchased responds to price and available income) and therefore higher incomes could also be associated with more smoking and drinking (Gallet, 2007; Kenkel et al., 2014). This could have deleterious effects on infant health. 
Third, and closely related to changes in health-related behavior, increases in the EITC likely reduces financial stress and increases income security of mothers. Previous work has established that in-utero exposure to elevated levels of stress negatively affects birth outcomes (Aizer et al., 2015; Camacho, 2008), while chronic maternal stress has been shown to slow down fetal growth rates and to increase the risk of preterm delivery (Weinstock, 2005). Evans and Garthwaite (2014) show that expansions of the federal EITC lessened the count of risky biomarkers in mothers, indicating reductions in stress. Lenhart (2015) provides suggestive evidence that higher minimum wages improve health outcomes by reducing financial stress of workers.

Health effects of state EITCs above the federal have received far less attention. Yet, state legislatures play an increasingly important role in setting social and health policy. Baughman and Duchovny (2016) examine the effects of the state credit on children's health insurance coverage, use of medical care and health status, and find no effects of the EITC on these outcomes for children ages 0-5. But they provide some evidence that the state EITC improves health for older children. Strully et al. (2010) evaluate the effects of state EITCs, through 2002, on infant birth weight and maternal prenatal smoking. They find that the presence of a state EITC is associated with increased birth weight and lower maternal smoking.

We advance the existing literature in several ways. First, we examine effects of changes in both the presence and generosity of states' EITC programs. Second, we include multiple infant health outcomes and maternal health behaviors, including timely receipt of prenatal care, maternal drinking and smoking, birth weight, and gestation length in order to advance understanding of possible mechanisms for EITC health effects. Third, we use birth certificate data spanning two decades, from 1994 to 2013. Data used by Strully et al. (2010) ended in 2002 
when only 16 states had an EITC and before many states significantly raised EITC generosity levels. Our expanded time period includes substantially more variation in the policy, improving power to identify effects on infant health outcomes.

\section{METHODS}

We use a multi-state, multi-year difference-in-differences research design to evaluate the effects of state EITCs on maternal and infant outcomes. Using birth certificate data from the National Vital Statistics System combined with measures of the generosity of state EITCs, our primary equations of interest are as follows:

$$
\begin{aligned}
& M H_{i c j t}=\beta_{1} E I T C_{j(t-g-1)}+\beta_{2} X_{i c j t}+\beta_{3} Z_{c j t}+\delta_{j}+\gamma_{(t-g)}+\varepsilon_{j t} \\
& I H_{i c j t}=\beta_{1} E I T C_{j(t-1)}+\beta_{2} X_{i c j t}+\beta_{3} Z_{c j t}+\delta_{j}+\gamma_{(t-g)}+\varepsilon_{j t}
\end{aligned}
$$

In equations $1 \mathrm{a}$ and $1 \mathrm{~b}$, the dependent variables are maternal health behaviors $(\mathrm{MH})$ and infant health (IH) outcomes (described below) for mother and child (i) in county (c) in state (j) in birth year (t). EITC are measures of the generosity of the state EITC (described below) in effect in the state at the relevant time, with consideration of gestation length $(\mathrm{g})$. The merging algorithm is also discussed below. The vector $X$ contains maternal characteristics available on the birth certificates; $Z$ represents county-level factors that may also influence the outcomes; and $\delta_{j}$ and $\gamma_{t}$ represent state fixed effects and conception year-by-quarter fixed effects, respectively. Details on all variables follow.

The study time period spans 1994-2013. We start with births occurring in 1995 (conceptions occurring in 1994) to capture the period after the major federal change in EITC payments in 1993 (implemented universally across all states). We use linear probability models to analyze the dichotomous variables and OLS to analyze average birth weight and gestational 
age. We also use unconditional quantile regression to further analyze birth weights. Standard errors in all models are adjusted for within-state serial correlation by clustering at the state level. We tested models using logit for the dichotomous outcomes and results and conclusions are unchanged.

\section{DATA}

\section{U.S. National Vital Statistics System Birth Data}

Maternal health variables, infant health variables, and maternal characteristics come from the U.S. National Vital Statistics System birth data. This source provides a $100 \%$ census of birth data annually. The maternal health behaviors $(M H)$ we study include indicators for receiving first trimester prenatal care, tobacco use during pregnancy, alcohol use during pregnancy, and adequate weight gain during pregnancy. The item regarding alcohol consumption was eliminated from birth certificates as of 2007 so results for this outcome are limited to 1994-2006. Infant health outcomes $(I H)$ include birth weight, probability of birth weight less than 2500 grams, and gestation weeks. Summary statistics for these and all other variables are shown in Table 1.

Maternal characteristics $(X)$ available on birth certificates include age, marital status, maternal education, and race/ethnicity. Geographic codes on the birth certificates allow us to identify the county in which the mother resides, unless the county is very small $(<100,000$ population). We use the geographic codes to merge in county-level covariates $(Z)$ potentially related to the outcomes. These include the county unemployment rate, real income per capita, percent poverty, number of obstetricians/gynecologists and primary care physicians per 1000 women ages 15-44, and county population size indicators. For cases in which we do not know 
the mother's county of residence, we use the average value for all counties in her state with a population less than 100,000 .

\section{U.S. State-level EITC Legal Data}

The main independent variables of interest reflect state-level EITC generosity and refundability as defined below. To generate these variables, we conducted original legal research to document state-level EITC policy for each of the 50 states, plus Washington DC. Policy coding was based on the effective date (not passage date) of legislative bills passed by legislatures and signed into law by state Governors, and then codified into statutory records. In collaboration with a team of legal researchers, we developed a codebook and detailed coding protocol to capture important EITC policy dimensions, including eligibility criteria, and amount and refundability of the tax credit.

We completed data collection and coding with extensive quality control procedures, including blinded independent coding of a random sample of items by two trained legal researchers. All legal coders were closely supervised by a senior attorney, who reviewed protocols with coders for any variable showing $5 \%$ or higher cross-coder disagreement rate. All divergences between two coders were resolved by the supervising attorney after meeting with the two coders and examining the original legal text.

If the state has an EITC, the value is usually expressed in the law as a percent of the federal EITC, but some states specify a dollar amount of the credit which we converted to a percent of federal based on the relevant federal dollar amount. The values of the state credits often vary based on number of children living in the household. In addition, some states specify that the EITC is refundable, meaning that if the tax liability falls to zero, the government will 
send a refund check for the credit amount. Nonrefundable credits provide no further income beyond a zero tax liability.

We use the information gathered to create a series of indicators combining the presence of and generosity of the EITC payments as follows: 1) states with no EITC (reference category); 2) states with an EITC, nonrefundable payments, and payments less than $10 \%$ of the federal amount; 3) states with an EITC, payments that are refundable, and payments less than $10 \%$ of the federal amount; 4) states with an EITC, nonrefundable payments, and payments 10\% or more of the federal amount; 5) states with an EITC, refundable payments, and payments 10\% or more of the federal amount. We use the $10 \%$ cutoff because this is the median value of EITC percentages among states over the sample period. The cutoff can be considered a measure of low generosity versus high generosity, with the caveat that the refund status also affects the level of generosity. The dollar amount of this $10 \%$ cutoff varies by year and family size. In 2013, the last year of our sample, the nominal dollar amount associated with this cutoff was $\$ 325$ for a family with one child, $\$ 357$ for a family with two children, and $\$ 604$ for a family with three or more children.

In 1994, 5 states had an EITC in place but by 2013 this number grew to 26 states, plus Washington DC. Maryland was excluded from our analysis because of the unique structure of their EITC law, which does not match the measurement model used for all the other states. We coded 80 changes in state EITC law from 1994 to 2013. After condensing these changes into our 5 policy categories, the 80 legal changes represented 34 shifts in categories across 23 states over the study period.

We assigned the state EITC indicator variables to the mothers in the birth certificate data based on the prior number of live births in order to accurately reflect the monetary value of the 
most recent payment the mothers may have received. For maternal health outcomes, which pertain to the period during pregnancy, we merged the EITC in the year prior to conception (t-g1) where $\mathrm{g}$ is gestation weeks as documented in the vital records. For example, for mothers who conceive in 2013, the most recent EITC received is based on earnings in 2012, with the refund actually arriving as disposable income in the first quarter of 2013. For infant outcomes, the relevant EITC is that which was received closest to the birth date. For births in the second, third and fourth quarters of a year, the relevant EITC is for earnings year t-1. For births in the first quarter of the year, the relevant EITC is earnings year t-2. Given this matching algorithm, 1994 is the first year of EITC payments that appear in our data and conception dates range from the first quarter of 1995 to the third quarter of 2013.

Given the information available on birth certificates, we cannot identify the individual women who assuredly qualify for the EITC. The best available solution to this problem is to use information on mother's education to limit the sample and estimate models that represent an approximation of intent-to-treat. Athreya et al. (2010) finds that $61.5 \%$ of EITC recipients have a high school education or less, therefore, we limit the sample to women with this level of education. This approach is common in the EITC literature (Evans \& Garthwaite, 2014; Hoynes et al., 2015; Strully et al., 2010). Education is missing from birth certificates for some states in the years 2009-2012, so by necessity, these states are omitted for these years. While our main models include all low-educated women, we present additional models based on marital status and number of children that may help further identify EITC eligible women. Bitler et al. (2016) examined EITC recipients by demographic group and show that the largest group of recipients are single with children (58.7\% in 2008). Married couples with children and childless individuals make up around 20 percent each. Nevertheless, our inability to determine individual-level EITC 
eligibility or actual receipt is an important limitation of our study and the results should be interpreted with this in mind.

Another potential limitation of our analysis arises if there are omitted time-varying factors that are correlated with both the outcomes and changes in our measures of EITC generosity. Our strategy of including the time varying county-level factors accounts for some of the unobserved environment. The overall generosity of a state's welfare package will be captured by the state fixed effects, and the year indicators will capture national changes in some policies. Our results could be biased if there are remaining time-varying factors, such as other social welfare policies, that are unaccounted for. However, for the omission of such policies to bias our estimates, changes in the EITC would have to be correlated with changes in the other policies. That is, states would have to make substantial legislative changes to other programs at the same time as changing the EITC. Changes to the EITC are typically made as part of changes to the tax code, making this scenario unlikely. As an example, we analyzed changes to Medicaid eligibility thresholds for pregnant women by state for the years 1997-2013. Medicaid pays for around $40 \%$ of all births in the United States, so Medicaid is the policy most likely to be correlated with EITC and the maternal and child outcomes we study. These statutory thresholds changed 38 times in 26 states over this period. We compared these dates to the dates of the EITC changes in the same states and find that only four coincide. We then re-ran our main models with and without the Medicaid eligibility thresholds. The results of the EITC are nearly identical to those presented below, providing evidence against omitted variable bias. These results are available upon request.

\section{RESULTS}


Table 2 shows results for maternal health behaviors (columns 1-4) and birth outcomes (columns 5-6) among women with a high school education or less. There are few statistically significant differences in maternal health behaviors associated with state-level EITC, although states with the lowest levels of EITC (<10 percent of federal) and no refund do have a higher probability of early prenatal care $(4.8$ percentage points [95\% CI $0.2,9.3])$ and a lower probability of maternal smoking (1.6 percentage points [95\% CI -2.3, -0.1]) relative to the period within the state with no EITC. States with time periods of high values of the EITC $(\geq 10$ percent of federal) but no refund are associated with a higher probability of adequate weight gain (2.2 percentage points $[95 \%$ CI $0.7,3.7])$.

By contrast, results for infant health outcomes of birth weight and gestation weeks consistently show improvements in states with any level of EITC. Average birth weights increase by a range of 9 to 27 grams, with the larger effects seen among the more generous state EITCs. This represents $0.3 \%$ to $0.8 \%$ increases in birth weight. In results shown in Figure 1, we ran quantile regression models to determine where along the distribution of birth weights the EITC has the largest effects. The quantile models show that the increase in birth weights happens across the entire distribution, but the largest effects occur at the lowest birth weights and among states with the most generous EITC. These results highlight the dose-response effect of the EITC, where more generous benefits are associated with the largest gains. For example, birth weights in states with a EITC $\geq 10$ percent of federal with a refund are higher by a range of 16 to 34 grams. The corresponding effects in states with an EITC $<10$ and no refund is 3-15 grams. The smallest of the babies, those in the $5^{\text {th }}$ to $20^{\text {th }}$ percentiles, have average increases of 21 to 34 grams ( $1 \%$ to $1.5 \%$ increase) in the most generous states and have an average increase of $7-15$ grams $(0.3 \%$ to $0.6 \%)$ in the least generous states. 
Column 6 of Table 2 shows the statistically significant reductions in probability of low birth weight (weight $<2500$ grams). The magnitude ranges from 0.3 to 0.8 percentage points, which represents $4 \%$ to $11 \%$ reductions in the mean of 7.1 percent. These results translate into reductions of 4,300 to 11,850 babies born low birth weight every year. Lastly, average gestation weeks also increase with the high-value state EITCs. The magnitudes reflect increases of less than a day and just over a day, representing $0.02 \%$ and $0.4 \%$ increases, for high-value EITCs with and without refunds, respectively. This finding is noteworthy given that the average birth is full term at around 39 weeks and it is very difficult to find factors that generate large changes around the mean.

In Table 3 we present results for different samples of low educated women: unmarried, married, first births, second or more births. As stated above, the division by marital status will help identify the women most likely to receive an EITC, with single parents being the group most commonly represented. The split among first births and second or more is important for the propensity to work and because many state and the federal EITC benefits become larger with family size.

The results for unmarried low-educated mothers (Panel A of Table 3) are very similar to the results show in Table 2 both in magnitude and statistical significance. Married low-educated women also seem to have similar responses to state EITCs as their unmarried counterparts, although the magnitudes are slightly lower for the maternal health behaviors.

The pattern of results remains similar when looking at birth parity. One notable difference that is present among first births (Panel C) is that some of the coefficients on the state EITC values are no longer statistically significant in birth weight and gestation models and the size of the effects fall. As described below, this group of women may be the least likely to work 
and be eligible for the EITC so the diminished effects are not surprising. However, the effects return among the women with previous births (Panel D) and the patterns are once again similar to those for all low-educated women.

\section{CONCLUSIONS}

Previous research has shown increases in infant birth weight in response to increased generosity of the U.S. federal EITC (Hoynes et al., 2015) and the mere presence of a state EITC (Strully et al., 2010). These studies also point to increased prenatal care and reduced maternal smoking as possible mechanisms through which the EITC affects infant health. Our study furthers this literature by capturing a sizable number of recent additions and changes to state EITCs, and by examining the health effects of both the presence and generosity of state EITCs. We confirm results of previous studies showing that improvements in birth weight grow with the generosity of state EITCs. Importantly, we find that the largest birth weight increases occurred at the lowest birth weights, and that prevalence of low-birth-weight births are reduced as EITC generosity increases. Moreover, the largest increases in birth weight and reductions in low birth weight births were in states with refundable EITCs - a form of dose-response effect. These results are tempered by the magnitudes of the effects. Our largest effects only increase birth weights by about 1.5 percent on average. What is unknown is whether this average is being generated by small changes among a lot of babies or very large changes in a few babies. Further study would be needed to answer this question.

We also show that gestation duration increases slightly along with state EITCs. Although small in magnitude, this result is noteworthy given that the average birth is full term at about 39 weeks and it is very difficult to find factors that generate noticeable changes around this mean. 
We also find consistent effects across subgroups of mothers defined by marital status and parity. However, we find very limited evidence supporting the hypothesized mechanisms of early prenatal care and reduced smoking.

An important limitation of our study is the inability to determine individual-level EITC eligibility or actual receipt. To reduce this limitation, we restricted the sample to low educated mothers to estimate models that more closely represent intent-to-treat since the majority of EITC recipients have a high school education or less (Athreya et al., 2010). Another limitation is our inconclusive evidence regarding mechanisms of effect of state-level EITC on birth outcomes. In our analyses, few of the maternal health behaviors appear to be affected by state EITC generosity. It may be that other unmeasured mechanisms are at play, including the potential for higher incomes brought on by the EITC to reduce financial or other stressors.

Since EITC benefits are tied to earned income and employment, a potential concern with our analysis exists if women do not work in the time periods surrounding the pregnancy. In a Current Population Report using data from the U.S. Census Bureau's Survey of Income and Program Participation, Laughlin (2011) shows a range of 65 to 69 percent of mothers worked during their first pregnancy in the years spanning 1991-2008. However, the number in recent years is lower for women with a high school education or less, with 42 percent working during a first pregnancy. Non-working women could still benefit from an EITC if they live with a spouse or unrelated adult whose income qualifies for the EITC. In addition, the annual nature of the EITC and the matching algorithm we use does not limit the eligibility period to just the months during pregnancy. Women who worked before pregnancy could qualify and still have their pregnancy outcomes affected by the EITC. Indeed, data from the CPS from 2003-2013 show 
that 81 to 85 percent of low-educated women ages 18-45 are employed annually (our calculations using CPS Table Creator).

We designed a strong quasi-experiment and multi-state and multi-year difference-indifferences analysis using original legal data collection to capture state changes to EITC laws and generosity. We analyzed 34 changes in EITC category across 20 years and 23 U.S. states, included state and year fixed effects to efficiently control for a host of potential confounders, and replicated results across three important birth outcomes. Our study, therefore, provides scientific evidence of small but important positive health effects of more generous state-level EITCs. Finally, the magnitudes of the effects we find are quite similar to the birth weight effects of a similar income boost from a completely different policy_minimum wage laws. Wehby et al. (2016) reports an increase in household income of $\$ 1000$ from an increase in minimum wage is associated with a 12 gram increase in birth weight and a $2.8 \%$ decrease in prevalence of low birth weight.

Low birth weight is a sensitive consequence of low income, has been established as one of the most important predictors of infant mortality, and increases the risk of deleterious health and economic effects into adulthood (Johnson \& Schoeni, 2011). Fifty-percent of women giving birth in the United States are 200 percent or below the federal poverty level (Monte \& Ellis, 2009). The federal EITC has been praised as the largest and most effective anti-poverty program for families in the U.S., and multiple studies have found positive health benefits as well. Despite bipartisan support, only 26 states and Washington DC have state-specific EITCs, which vary greatly in generosity. We found that state-level EITC laws and level of generosity of EITCs is associated with small but important improvements in birth outcomes, providing evidence for the health benefits of state-level EITCs. 


\section{References}

Aizer, A., Stroud, L., \& Buka, S. (2015). Maternal stress and child outcomes: Evidence from siblings. Journal of Human Resources.

Almond, D., \& Currie, J. (2011). Killing me softly: The fetal origins hypothesis. The Journal of Economic Perspectives, 25, 153-172.

Athreya, K., Reilly, D., \& Simpson, N.B. (2010). Earned Income Tax Credit recipients: income, marginal tax rates, wealth, and credit constraints. Economic Quarterly, 96, 229-258.

Averett, S., \& Wang, Y. (2013). The Effects of Earned Income Tax Credit Payment Expansion on Maternal Smoking. Health Economics, 22, 1344-1359.

Baker, K. (2008). Do cash transfer programs improve infant health: Evidence from the 1993 expansion of the earned income tax credit. manuscript, University of Notre Dame.

Baughman, R.A., \& Duchovny, N. (2016). State Earned Income Tax Credits and the production of child health: Insurance coverage, utilization, and health status. National Tax Journal, 69, 103.

Bitler, M., Hoynes, H., \& Kuka, E. (2016). Do In-Work Tax Credits Serve as a Safety Net? Journal of Human Resources.

Backlund, E., Sorlie, P. D., \& Johnson, N. J. (1996). The shape of the relationship between income and mortality in the United States: evidence from the National Longitudinal Mortality Study. Annals of epidemiology, 6(1), 12-20.

Boyd-Swan, C., Herbst, C.M., Ifcher, J., \& Zarghamee, H. (2016). The earned income tax credit, mental health, and happiness. Journal of Economic Behavior \& Organization, 126, 18 38.

Camacho, A. (2008). Stress and birth weight: evidence from terrorist attacks. The American Economic Review, 98, 511-515.

Case, A., Lubotsky, D., \& Paxson, C. (2002). Economic status and health in childhood: The origins of the gradient. The American Economic Review, 92, 1308-1334.

Chetty, R., Stepner, M., Abraham, S., Lin, S., Scuderi, B., Turner, N., et al. (2016). The association between income and life expectancy in the United States, 2001-2014. JAMA, 315, 1750-1766.

Eissa, N., \& Hoynes, H.W. (2006). Behavioral responses to taxes: Lessons from the EITC and labor supply. Tax policy and the economy, 20, 73-110.

Eissa, N., \& Liebman, J.B. (1996). Labor supply response to the earned income tax credit. The quarterly journal of economics, 111, 605-637.

Evans, W.N., \& Garthwaite, C.L. (2014). Giving mom a break: The impact of higher EITC payments on maternal health. American Economic Journal: Economic Policy, 6, 258-290.

Gallet, C.A. (2007). The demand for alcohol: a meta-analysis of elasticities. Australian Journal of Agricultural and Resource Economics, 51, 121-135.

Grossman, M. (1972). On the concept of health capital and the demand for health. Journal of Political economy, 80, 223-255.

Hamad, R., \& Rehkopf, D.H. (2015). Poverty, pregnancy, and birth outcomes: a study of the Earned Income Tax Credit. Paediatric and perinatal epidemiology, 29, 444-452.

Hotz, V.J. (2003). The earned income tax credit. Means-tested transfer programs in the United States pp. 141-198): University of Chicago press.

Hoynes, H. (2016). The Earned Income Tax Credit: A key policy to support families facing wage stagnation. Policy Brief. Institute for Research on Labor and Employment, University of California Berkley. 
Hoynes, H., Miller, D., \& Simon, D. (2015). Income, the earned income tax credit, and infant health. American Economic Journal: Economic Policy, 7, 172-211.

Hoynes, H. \& Patel, A. (forthcoming) "Effective Policy for Reducing Inequality? The Earned Income Tax Credit and the Distribution of Income," Journal of Human Resources

Internal Revenue Service. (2017). Income Limits and Range of EITC.

Johnson, R.C., \& Schoeni, R.F. (2011). The influence of early-life events on human capital, health status, and labor market outcomes over the life course. The BE journal of economic analysis \& policy, 11.

Kenkel, D.S., Schmeiser, M.D., \& Urban, C. (2014). Is smoking inferior? Evidence from variation in the earned income tax credit. Journal of Human Resources, 49, 1094-1120.

Laughlin, L. (2011). Maternity Leave and Employment Patterns of First-Time Mothers 19612008. Current Population Reports. US Census Bureau.

Lenhart, O. (2015). Do Higher Minimum Wages Benefit Health? Evidence from the UK.

Lenhart, O. (2016). Effects of the Earned Income Tax Credit on Health, Health Insurance and Food Expenditures.

Marr, C., Huang, C.-C., Sherman, A., \& DeBot, B. (2015). EITC and Child Tax Credit promote work, reduce poverty, and support children's development, research finds. Center on Budget and Policy Priorities.

McGranahan, L., \& Schanzenbach, D.W. (2013). The earned income tax credit and food consumption patterns.

Meyer, B.D. (2010). The effects of the Earned Income Tax Credit and recent reforms. Tax policy and the economy, 24, 153-180.

Meyer, B.D., \& Rosenbaum, D.T. (2001). Welfare, the earned income tax credit, and the labor supply of single mothers. The quarterly journal of economics, 116, 1063-1114.

Monte, L.M., \& Ellis, R.R. (2009). Fertility of women in the United States: 2012. Economics, 24, 1071-1100.

Neumark, D., \& Wascher, W. (2000). Using the EITC to Help Poor Families: New Evidence and a Comparision with the Minimum Wage. National bureau of economic research.

Nichols, A., \& Rothstein, J. (2016). The Earned Income Tax Credit" in Economics of MeansTested Transfer Programs in the United States Chicago: University of Chicago Press.

Pega, F., Carter, K., Blakely, T., \& Lucas, P.J. (2013). In-work tax credits for families and their impact on health status in adults. The Cochrane Library.

Pega, F., Gilsanz, P., Kawachi, I., Wilson, N., \& Blakely, T. (2017). Cumulative receipt of an anti-poverty tax credit for families did not impact tobacco smoking among parents. Social Science and Medicine, 179, 160-165.

Sorlie, P. D., Backlund, E., \& Keller, J. B. (1995). US mortality by economic, demographic, and social characteristics: the National Longitudinal Mortality Study. American Journal of Public Health, 85(7), 949-956.

Strully, K.W., Rehkopf, D.H., \& Xuan, Z. (2010). Effects of Prenatal Poverty on Infant Health : State Earned Income Tax Credits and Birth Weight. American Sociological Review, 75, 534-562.

Wehby, G., Dave, D., \& Kaestner, R. (2016). Effects of the minimum wage on infant health. National Bureau of Economic Research.

Weinstock, M. (2005). The potential influence of maternal stress hormones on development and mental health of the offspring. Brain, behavior, and immunity, 19, 296-308. 


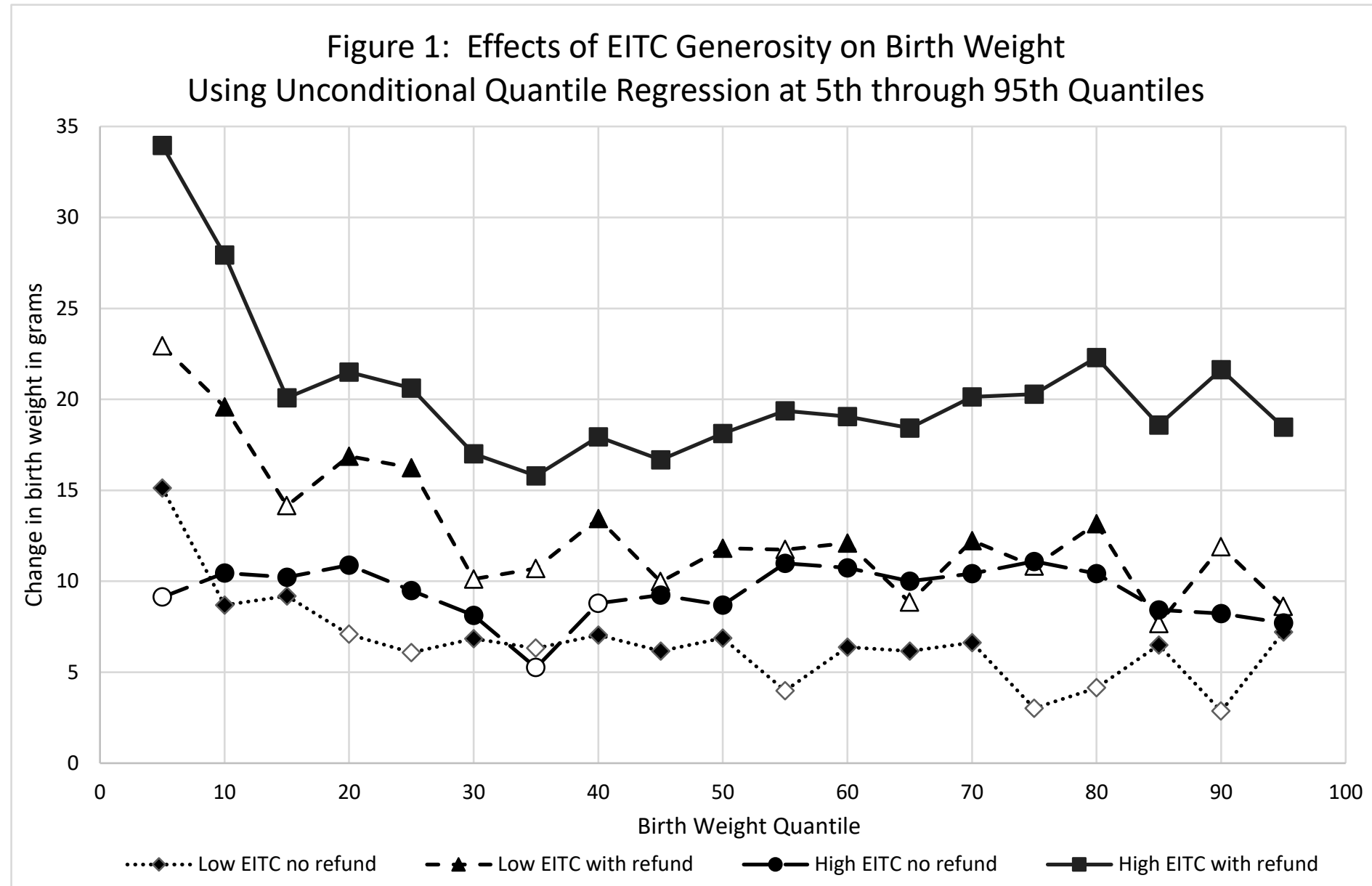

Note: $\mathrm{N}=30,780,950$. Solid marker indicates point estimate is statistically significant at the $5 \%$ level. 
Table 1: Summary Statistics (N=30,802,189)

\begin{tabular}{|c|c|c|c|c|}
\hline Variables & Mean & $\begin{array}{l}\text { Std. } \\
\text { Dev }\end{array}$ & Min & $\operatorname{Max}$ \\
\hline \multicolumn{5}{|l|}{ Dependent variables: Maternal Health Behaviors } \\
\hline $1^{\text {st }}$ Trimester Prenatal Care & 0.73 & 0.45 & 0 & 1 \\
\hline Smoked & 0.17 & 0.38 & 0 & 1 \\
\hline Drank alcohol (1994-2006) & 0.01 & 0.10 & 0 & 1 \\
\hline Adequate Weight Gain & 0.33 & 0.47 & 0 & 1 \\
\hline \multicolumn{5}{|l|}{ Dependent variables: Infant Health } \\
\hline Birth Weight & 3280.36 & 576.65 & 227 & 8165 \\
\hline Birth Weight $<2500 \mathrm{~g}$ & 0.07 & 0.26 & 0 & 1 \\
\hline Gestation Weeks & 38.75 & 2.58 & 17 & 47 \\
\hline \multicolumn{5}{|l|}{ State EITC variables (No State EITC omitted reference) } \\
\hline Low EITC no refund & 0.04 & 0.19 & 0 & 1 \\
\hline Low EITC with refund & 0.05 & 0.23 & 0 & 1 \\
\hline High EITC no refund & 0.01 & 0.07 & 0 & 1 \\
\hline High EITC with refund & 0.12 & 0.33 & 0 & 1 \\
\hline \multicolumn{5}{|l|}{ Individual-Level Covariates } \\
\hline Maternal age & 25.65 & 5.73 & 18 & 54 \\
\hline Married & 0.49 & 0.50 & 0 & 1 \\
\hline Female baby & 0.49 & 0.50 & 0 & 1 \\
\hline Black & 0.17 & 0.38 & 0 & 1 \\
\hline Native American & 0.01 & 0.12 & 0 & 1 \\
\hline Asian & 0.03 & 0.18 & 0 & 1 \\
\hline Hispanic & 0.33 & 0.47 & 0 & 1 \\
\hline Less than high school & 0.38 & 0.49 & 0 & 1 \\
\hline Hispanic ethnicity missing & 0.01 & 0.08 & 0 & 1 \\
\hline \multicolumn{5}{|l|}{ County-Level Covariates } \\
\hline Unemployment & 6.21 & 2.75 & 0.8 & 31 \\
\hline Real income per capita (in $\$ 1000$ s) & 16.50 & 4.67 & 2.64 & 64.03 \\
\hline Percent poverty & 14.57 & 5.41 & 2.2 & 62 \\
\hline Primary care physicians per 1000 females age $15-44$ & 1.90 & 0.70 & 0 & 29.85 \\
\hline County pop 500,000-1,000,000 & 0.17 & 0.37 & 0 & 1 \\
\hline County pop $250,000-500,000$ & 0.14 & 0.35 & 0 & 1 \\
\hline County pop $100,000-250,000$ & 0.15 & 0.36 & 0 & 1 \\
\hline County pop $<100,000$ & 0.26 & 0.44 & 0 & 1 \\
\hline
\end{tabular}


Table 2: Effects of Presence and Generosity of EITC Laws Among Low Educated Mothers

\begin{tabular}{|c|c|c|c|c|c|c|c|}
\hline & $\begin{array}{c}\text { (1) } \\
\text { 1st Trimester } \\
\text { Prenatal Care }\end{array}$ & $\begin{array}{c}(2) \\
\text { Smoked }\end{array}$ & $\begin{array}{c}(3) \\
\text { Drank alcohol } \\
(1994-2006)\end{array}$ & $\begin{array}{c}\text { (4) } \\
\text { Adequate } \\
\text { Weight Gain }\end{array}$ & $\begin{array}{c}\text { (5) } \\
\text { Birth Weight }\end{array}$ & $\begin{array}{c}\text { (6) } \\
\text { Birth } \\
\text { Weight }<2500 \mathrm{~g}\end{array}$ & $\begin{array}{c}(7) \\
\text { Gestation } \\
\text { Weeks }\end{array}$ \\
\hline Low EITC no refund & $\begin{array}{l}0.048 \\
(2.09)\end{array}$ & $\begin{array}{l}-0.016 \\
(-4.56)\end{array}$ & $\begin{array}{c}0.00004 \\
(0.05)\end{array}$ & $\begin{array}{l}0.005 \\
(0.94)\end{array}$ & $\begin{array}{l}9.441 \\
(2.62)\end{array}$ & $\begin{array}{l}-0.003 \\
(-2.99)\end{array}$ & $\begin{array}{l}0.048 \\
(1.66)\end{array}$ \\
\hline Low EITC with refund & $\begin{array}{l}-0.006 \\
(-0.32)\end{array}$ & $\begin{array}{l}-0.006 \\
(-1.29)\end{array}$ & $\begin{array}{l}-0.002 \\
(-1.82)\end{array}$ & $\begin{array}{c}-0.0005 \\
(-0.08)\end{array}$ & $\begin{array}{l}16.845 \\
(2.45)\end{array}$ & $\begin{array}{l}-0.005 \\
(-2.72)\end{array}$ & $\begin{array}{l}0.026 \\
(0.69)\end{array}$ \\
\hline High EITC no refund & $\begin{array}{l}0.025 \\
(1.13)\end{array}$ & $\begin{array}{l}0.009 \\
(1.91)\end{array}$ & $\begin{array}{c}0.0001 \\
(0.18)\end{array}$ & $\begin{array}{l}0.022 \\
(2.95)\end{array}$ & $\begin{array}{l}12.681 \\
(3.45)\end{array}$ & $\begin{array}{l}-0.003 \\
(-3.03)\end{array}$ & $\begin{array}{l}0.165 \\
(9.84)\end{array}$ \\
\hline High EITC with refund & $\begin{array}{l}-0.014 \\
(-0.64)\end{array}$ & $\begin{array}{l}0.007 \\
(0.90)\end{array}$ & $\begin{array}{l}-0.001 \\
(-0.44)\end{array}$ & $\begin{array}{c}-0.0002 \\
(-0.03)\end{array}$ & $\begin{array}{r}27.307 \\
(4.49)\end{array}$ & $\begin{array}{l}-0.008 \\
(-4.23)\end{array}$ & $\begin{array}{l}0.077 \\
(2.46)\end{array}$ \\
\hline Maternal age & $\begin{array}{l}0.002 \\
(5.77)\end{array}$ & $\begin{array}{l}0.001 \\
(4.16)\end{array}$ & $\begin{array}{c}0.001 \\
(13.55)\end{array}$ & $\begin{array}{c}-0.0004 \\
(-4.47)\end{array}$ & $\begin{array}{l}3.047 \\
(8.18)\end{array}$ & $\begin{array}{c}0.001 \\
(10.28)\end{array}$ & $\begin{array}{c}-0.027 \\
(-30.22)\end{array}$ \\
\hline Married & $\begin{array}{c}0.079 \\
(23.17)\end{array}$ & $\begin{array}{l}-0.116 \\
(-8.28)\end{array}$ & $\begin{array}{c}-0.011 \\
(-14.16)\end{array}$ & $\begin{array}{l}0.018 \\
(6.80)\end{array}$ & $\begin{array}{l}75.113 \\
(12.11)\end{array}$ & $\begin{array}{c}-0.021 \\
(-11.38)\end{array}$ & $\begin{array}{c}0.132 \\
(12.92)\end{array}$ \\
\hline Female baby & $\begin{array}{c}0.003 \\
(16.21)\end{array}$ & $\begin{array}{c}-0.0004 \\
(-2.85)\end{array}$ & $\begin{array}{c}0.00001 \\
(0.21)\end{array}$ & $\begin{array}{l}0.001 \\
(2.32)\end{array}$ & $\begin{array}{r}-107.567 \\
(-67.56)\end{array}$ & $\begin{array}{l}0.011 \\
(9.99)\end{array}$ & $\begin{array}{c}0.130 \\
(43.98)\end{array}$ \\
\hline Black & $\begin{array}{c}-0.080 \\
(-17.33)\end{array}$ & $\begin{array}{c}-0.159 \\
(-13.09)\end{array}$ & $\begin{array}{l}0.003 \\
(3.16)\end{array}$ & $\begin{array}{c}-0.024 \\
(-15.58)\end{array}$ & $\begin{array}{c}-170.484 \\
(-27.39)\end{array}$ & $\begin{array}{c}0.045 \\
(28.03)\end{array}$ & $\begin{array}{c}-0.489 \\
(-36.69)\end{array}$ \\
\hline Native American & $\begin{array}{c}-0.091 \\
(-12.14)\end{array}$ & $\begin{array}{l}-0.060 \\
(-1.89)\end{array}$ & $\begin{array}{l}0.017 \\
(4.40)\end{array}$ & $\begin{array}{l}-0.025 \\
(-8.78)\end{array}$ & $\begin{array}{c}58.162 \\
(6.00)\end{array}$ & $\begin{array}{l}-0.006 \\
(-2.48)\end{array}$ & $\begin{array}{l}-0.073 \\
(-2.14)\end{array}$ \\
\hline Asian & $\begin{array}{c}-0.092 \\
(-12.04)\end{array}$ & $\begin{array}{c}-0.174 \\
(-19.29)\end{array}$ & $\begin{array}{l}-0.008 \\
(-8.75)\end{array}$ & $\begin{array}{l}0.030 \\
(6.64)\end{array}$ & $\begin{array}{c}-127.716 \\
(-18.68)\end{array}$ & $\begin{array}{l}0.006 \\
(4.72)\end{array}$ & $\begin{array}{l}-0.131 \\
(-5.66)\end{array}$ \\
\hline Hispanic & $\begin{array}{l}-0.052 \\
(-5.39)\end{array}$ & $\begin{array}{c}-0.229 \\
(-16.97)\end{array}$ & $\begin{array}{c}-0.008 \\
(-13.96)\end{array}$ & $\begin{array}{l}0.013 \\
(4.40)\end{array}$ & $\begin{array}{c}23.430 \\
(3.27)\end{array}$ & $\begin{array}{l}-0.015 \\
(-6.68)\end{array}$ & $\begin{array}{l}0.006 \\
(0.24)\end{array}$ \\
\hline Less than high school & $\begin{array}{c}-0.092 \\
(-10.85)\end{array}$ & $\begin{array}{l}0.090 \\
(9.49)\end{array}$ & $\begin{array}{l}0.005 \\
(9.75)\end{array}$ & $\begin{array}{l}-0.021 \\
(-6.48)\end{array}$ & $\begin{array}{c}-33.838 \\
(-6.23)\end{array}$ & $\begin{array}{l}0.009 \\
(6.22)\end{array}$ & $\begin{array}{l}-0.027 \\
(-2.67)\end{array}$ \\
\hline Unemployment & $\begin{array}{l}-0.002 \\
(-2.48)\end{array}$ & $\begin{array}{l}-0.001 \\
(-1.15)\end{array}$ & $\begin{array}{c}-0.0003 \\
(-2.21)\end{array}$ & $\begin{array}{l}0.003 \\
(1.08)\end{array}$ & $\begin{array}{l}2.179 \\
(2.41)\end{array}$ & $\begin{array}{l}-0.001 \\
(-3.34)\end{array}$ & $\begin{array}{l}0.006 \\
(1.21)\end{array}$ \\
\hline Real income per capita & $\begin{array}{l}-0.002 \\
(-1.50)\end{array}$ & $\begin{array}{l}-0.002 \\
(-4.23)\end{array}$ & $\begin{array}{c}-0.0001 \\
(-1.49)\end{array}$ & $\begin{array}{l}0.001 \\
(3.95)\end{array}$ & $\begin{array}{l}0.773 \\
(1.61)\end{array}$ & $\begin{array}{c}-0.0002 \\
(-3.20)\end{array}$ & $\begin{array}{l}0.004 \\
(1.55)\end{array}$ \\
\hline Percent poverty & -0.001 & -0.001 & -0.00001 & -0.001 & -2.711 & 0.001 & -0.007 \\
\hline
\end{tabular}




\begin{tabular}{|c|c|c|c|c|c|c|c|}
\hline & $(-1.00)$ & $(-1.64)$ & $(-0.14)$ & $(-2.37)$ & $(-7.14)$ & $(7.84)$ & $(-3.11)$ \\
\hline Primary care physicians & 0.012 & 0.010 & 0.002 & -0.002 & -4.135 & 0.002 & -0.004 \\
\hline per cap. & $(2.75)$ & $(3.29)$ & $(4.68)$ & $(-1.39)$ & $(-2.93)$ & $(4.40)$ & $(-0.51)$ \\
\hline $\mathrm{N}$ & 29858196 & 25998369 & 15990278 & 25846729 & 30780950 & 30780950 & 30802189 \\
\hline
\end{tabular}

Note: $t$ statistics in parentheses. Models also contain indicator variables for unknown Hispanic ethnicity and county population size as shown in Table 1. All models include state fixed effect and year-by-quarter fixed effects. Standard errors adjusted for clustering at the state level. 
Table 3: Effects of Presence and Generosity of EITC Laws, Low Educated Mothers, By Family Structure Subgroup

\begin{tabular}{|c|c|c|c|c|c|c|c|}
\hline $\begin{array}{l}\text { PANEL A } \\
\text { Single }\end{array}$ & $\begin{array}{c}\text { (1) } \\
\text { 1st Trimester } \\
\text { Prenatal Care } \\
\end{array}$ & $\begin{array}{c}(2) \\
\text { Smoked }\end{array}$ & $\begin{array}{c}(3) \\
\text { Drank alcohol } \\
(1994-2006) \\
\end{array}$ & $\begin{array}{c}\text { (4) } \\
\text { Adequate } \\
\text { Weight Gain } \\
\end{array}$ & $\begin{array}{c}(5) \\
\text { Birth Weight }\end{array}$ & $\begin{array}{c}\text { (6) } \\
\text { Birth } \\
\text { Weight }<2500 \mathrm{~g}\end{array}$ & $\begin{array}{c}(7) \\
\text { Gestation } \\
\text { Weeks } \\
\end{array}$ \\
\hline Low EITC no refund & $\begin{array}{l}0.052 \\
(2.04)\end{array}$ & $\begin{array}{l}-0.022 \\
(-3.79)\end{array}$ & $\begin{array}{c}-0.0001 \\
(-0.08)\end{array}$ & $\begin{array}{l}0.004 \\
(0.59)\end{array}$ & $\begin{array}{l}11.837 \\
(2.48)\end{array}$ & $\begin{array}{l}-0.004 \\
(-3.28)\end{array}$ & $\begin{array}{l}0.063 \\
(1.70)\end{array}$ \\
\hline Low EITC with refund & $\begin{array}{l}-0.012 \\
(-0.60)\end{array}$ & $\begin{array}{l}-0.007 \\
(-0.86)\end{array}$ & $\begin{array}{l}-0.003 \\
(-2.07)\end{array}$ & $\begin{array}{l}-0.002 \\
(-0.34)\end{array}$ & $\begin{array}{l}17.055 \\
(2.67)\end{array}$ & $\begin{array}{l}-0.006 \\
(-2.84)\end{array}$ & $\begin{array}{l}0.042 \\
(0.94)\end{array}$ \\
\hline High EITC no refund & $\begin{array}{l}0.022 \\
(0.98)\end{array}$ & $\begin{array}{l}0.012 \\
(1.94)\end{array}$ & $\begin{array}{l}0.001 \\
(1.69)\end{array}$ & $\begin{array}{l}0.020 \\
(2.80)\end{array}$ & $\begin{array}{l}15.212 \\
(3.41)\end{array}$ & $\begin{array}{l}-0.003 \\
(-1.85)\end{array}$ & $\begin{array}{l}0.162 \\
(7.21)\end{array}$ \\
\hline High EITC with refund & $\begin{array}{l}-0.011 \\
(-0.54)\end{array}$ & $\begin{array}{l}0.012 \\
(0.85)\end{array}$ & $\begin{array}{l}-0.001 \\
(-0.34)\end{array}$ & $\begin{array}{l}0.002 \\
(0.33)\end{array}$ & $\begin{array}{l}23.086 \\
(4.21)\end{array}$ & $\begin{array}{l}-0.008 \\
(-4.06)\end{array}$ & $\begin{array}{l}0.075 \\
(1.91)\end{array}$ \\
\hline $\mathrm{N}$ & 15003775 & 13244060 & 7521230 & 13218409 & 15545644 & 15545644 & 15557589 \\
\hline \multicolumn{8}{|l|}{$\begin{array}{l}\text { PANEL B } \\
\text { Married }\end{array}$} \\
\hline Low EITC no refund & $\begin{array}{l}0.044 \\
(2.18)\end{array}$ & $\begin{array}{l}-0.008 \\
(-2.86)\end{array}$ & $\begin{array}{l}0.0003 \\
(0.48)\end{array}$ & $\begin{array}{l}0.006 \\
(1.07)\end{array}$ & $\begin{array}{l}8.101 \\
(2.56)\end{array}$ & $\begin{array}{l}-0.002 \\
(-2.56)\end{array}$ & $\begin{array}{l}0.033 \\
(1.59)\end{array}$ \\
\hline Low EITC with refund & $\begin{array}{l}0.002 \\
(0.08)\end{array}$ & $\begin{array}{l}-0.006 \\
(-1.22)\end{array}$ & $\begin{array}{l}-0.002 \\
(-2.12)\end{array}$ & $\begin{array}{l}0.001 \\
(0.09)\end{array}$ & $\begin{array}{l}18.310 \\
(2.35)\end{array}$ & $\begin{array}{l}-0.005 \\
(-2.63)\end{array}$ & $\begin{array}{l}0.009 \\
(0.27)\end{array}$ \\
\hline High EITC no refund & $\begin{array}{l}0.026 \\
(1.20)\end{array}$ & $\begin{array}{l}0.008 \\
(1.58)\end{array}$ & $\begin{array}{c}-0.0001 \\
(-0.26)\end{array}$ & $\begin{array}{l}0.023 \\
(3.29)\end{array}$ & $\begin{array}{l}10.795 \\
(2.92)\end{array}$ & $\begin{array}{l}-0.003 \\
(-4.53)\end{array}$ & $\begin{array}{c}0.169 \\
(15.23)\end{array}$ \\
\hline High EITC with refund & $\begin{array}{l}-0.014 \\
(-0.64)\end{array}$ & $\begin{array}{l}0.005 \\
(0.73)\end{array}$ & $\begin{array}{l}-0.001 \\
(-0.99)\end{array}$ & $\begin{array}{l}-0.001 \\
(-0.23)\end{array}$ & $\begin{array}{l}32.010 \\
(3.97)\end{array}$ & $\begin{array}{l}-0.008 \\
(-4.12)\end{array}$ & $\begin{array}{l}0.075 \\
(2.82)\end{array}$ \\
\hline $\mathrm{N}$ & 14854421 & 12754309 & 8469048 & 12628320 & 15235306 & 15235306 & 15244600 \\
\hline
\end{tabular}


Table 3 (Cont.): Effects of Presence and Generosity of EITC Laws, Low Educated Mothers, By Family Structure Subgroup

\begin{tabular}{|c|c|c|c|c|c|c|c|}
\hline $\begin{array}{l}\text { PANEL C } \\
\text { First Birth }\end{array}$ & $\begin{array}{c}\text { (1) } \\
\text { 1st Trimester } \\
\text { Prenatal Care }\end{array}$ & $\begin{array}{c}(2) \\
\text { Smoked }\end{array}$ & $\begin{array}{c}(3) \\
\text { Drank alcohol } \\
(1994-2006)\end{array}$ & $\begin{array}{c}\text { (4) } \\
\text { Adequate } \\
\text { Weight Gain }\end{array}$ & $\begin{array}{c}\text { (5) } \\
\text { Birth Weight }\end{array}$ & $\begin{array}{c}(6) \\
\text { Birth } \\
\text { Weight }<2500 \mathrm{~g}\end{array}$ & $\begin{array}{c}(7) \\
\text { Gestation } \\
\text { Weeks }\end{array}$ \\
\hline Low EITC no refund & $\begin{array}{l}0.046 \\
(2.27)\end{array}$ & $\begin{array}{l}-0.020 \\
(-4.64)\end{array}$ & $\begin{array}{l}0.001 \\
(0.64)\end{array}$ & $\begin{array}{l}0.010 \\
(1.83)\end{array}$ & $\begin{array}{l}4.251 \\
(0.98)\end{array}$ & $\begin{array}{l}-0.002 \\
(-2.86)\end{array}$ & $\begin{array}{l}0.042 \\
(1.43)\end{array}$ \\
\hline Low EITC with refund & $\begin{array}{l}-0.004 \\
(-0.19)\end{array}$ & $\begin{array}{l}-0.011 \\
(-2.42)\end{array}$ & $\begin{array}{l}-0.001 \\
(-0.68)\end{array}$ & $\begin{array}{l}-0.001 \\
(-0.10)\end{array}$ & $\begin{array}{l}7.440 \\
(1.32)\end{array}$ & $\begin{array}{l}-0.003 \\
(-1.95)\end{array}$ & $\begin{array}{l}0.042 \\
(1.13)\end{array}$ \\
\hline High EITC no refund & $\begin{array}{l}0.030 \\
(1.49)\end{array}$ & $\begin{array}{l}0.004 \\
(0.77)\end{array}$ & $\begin{array}{l}0.001 \\
(2.67)\end{array}$ & $\begin{array}{l}0.024 \\
(3.18)\end{array}$ & $\begin{array}{l}10.502 \\
(3.38)\end{array}$ & $\begin{array}{l}-0.002 \\
(-1.85)\end{array}$ & $\begin{array}{c}0.172 \\
(10.41)\end{array}$ \\
\hline High EITC with refund & $\begin{array}{l}0.010 \\
(0.48)\end{array}$ & $\begin{array}{l}-0.002 \\
(-0.21)\end{array}$ & $\begin{array}{c}0.0002 \\
(0.18)\end{array}$ & $\begin{array}{c}-0.0003 \\
(-0.03)\end{array}$ & $\begin{array}{l}14.281 \\
(2.70)\end{array}$ & $\begin{array}{l}-0.004 \\
(-2.03)\end{array}$ & $\begin{array}{l}0.123 \\
(3.45)\end{array}$ \\
\hline $\mathrm{N}$ & 10287473 & 8992023 & 5630095 & 9015758 & 10574349 & 10574349 & 10582241 \\
\hline \multicolumn{8}{|l|}{$\begin{array}{l}\text { PANEL D } \\
\text { Second+ Birth }\end{array}$} \\
\hline Low EITC no refund & $\begin{array}{l}0.052 \\
(2.25)\end{array}$ & $\begin{array}{l}-0.016 \\
(-4.55)\end{array}$ & $\begin{array}{c}-0.0002 \\
(-0.31)\end{array}$ & $\begin{array}{l}0.003 \\
(0.43)\end{array}$ & $\begin{array}{l}8.912 \\
(2.31)\end{array}$ & $\begin{array}{l}-0.002 \\
(-1.76)\end{array}$ & $\begin{array}{l}0.062 \\
(2.42)\end{array}$ \\
\hline Low EITC with refund & $\begin{array}{l}0.006 \\
(0.26)\end{array}$ & $\begin{array}{l}-0.013 \\
(-2.25)\end{array}$ & $\begin{array}{l}-0.003 \\
(-1.99)\end{array}$ & $\begin{array}{l}-0.002 \\
(-0.26)\end{array}$ & $\begin{array}{l}12.198 \\
(2.28)\end{array}$ & $\begin{array}{l}-0.004 \\
(-2.47)\end{array}$ & $\begin{array}{l}0.047 \\
(1.22)\end{array}$ \\
\hline High EITC no refund & $\begin{array}{l}0.025 \\
(1.09)\end{array}$ & $\begin{array}{l}0.010 \\
(1.85)\end{array}$ & $\begin{array}{l}-0.001 \\
(-1.69)\end{array}$ & $\begin{array}{l}0.020 \\
(2.71)\end{array}$ & $\begin{array}{l}12.060 \\
(3.06)\end{array}$ & $\begin{array}{l}-0.003 \\
(-3.36)\end{array}$ & $\begin{array}{c}0.164 \\
(10.05)\end{array}$ \\
\hline High EITC with refund & $\begin{array}{l}-0.001 \\
(-0.04)\end{array}$ & $\begin{array}{l}-0.003 \\
(-0.33)\end{array}$ & $\begin{array}{l}-0.002 \\
(-0.88)\end{array}$ & $\begin{array}{l}-0.001 \\
(-0.24)\end{array}$ & $\begin{array}{l}17.704 \\
(3.61)\end{array}$ & $\begin{array}{l}-0.005 \\
(-4.46)\end{array}$ & $\begin{array}{l}0.109 \\
(3.31)\end{array}$ \\
\hline $\mathrm{N}$ & 19570723 & 17006346 & 10360183 & 16830971 & 20206601 & 20206601 & 20219948 \\
\hline
\end{tabular}

